\title{
ANATOMICAL TRAITS OF SWEET PEPPER (Capsicum annuum L.) FRUIT
}

\author{
${ }^{1}$ Elżbieta Weryszko-Chmielewska, ${ }^{2}$ Zenia Michałojć
}

\author{
${ }^{1}$ Department of Botany, University of Life Sciences in Lublin, Akademicka 15, 20-950 Lublin, Poland \\ ${ }^{2}$ Department of Soil Cultivation and Fertilization of Horticultural Plants, University of Life Sciences in Lublin, \\ Leszczyńskiego 58, 20-068 Lublin, Poland \\ e-mail: elzbieta.weryszko@up.lublin.pl
}

Received: 14.10 .2011

\section{Abstract}

The micromorphology of the epidermis as well as the anatomy of the pericarp and fruit pedicle in Capsicum annuum L., cv. 'Red Knight $\mathrm{F}_{1}$ ', were studied using light and scanning electron microscopy. The pericarp was found to consist of an epidermis with strongly thickened outer walls, several layers of tangential and angular collenchyma as well as multi-layered parenchyma composed of cells of varying size in which very large lobed nuclei were observed. Chromoplasts were found in the cells of the above-mentioned tissues. The inner epidermis of the pericarp was characterized by thick cell walls and numerous straight pits.

Among the tissues of the fruit pedicle, we observed epidermis with numerous stomata, collenchyma, chlorenchyma with very large intercellular spaces, small clusters of sclerenchyma, secondary phloem and xylem as well live and dead cells of the pith which were characterized by the presence of thin walls with numerous pits. The structural traits of the pericarp of the red pepper cultivar under study show adaptations to significantly reduced transpiration, which is an important feature during storage. At the same time, the strongly thickened and cutinized walls of the fruit contribute to a reduction in its digestibility and impede nutrient penetration in non-root feeding.

Key words: Capsicum annuum, fruit, pericarp, pedicle, epidermis, micromorphology, anatomy

\section{INTRODUCTION}

Sweet pepper (Capsicum annuиm L.) is native to Mexico and Guatemala. It belongs to the oldest cultivated plants in America and is known to have been cultivated since prehistoric times. In Europe it was first brought for cultivation in Spain and Germany in the 16th century (N o w i ń s k i, 1977). Red pepper is grown on a large-scale in the hot and warm temperate climate zones. In Poland sweet pepper in grown in shade houses and in open field (P o d b i e lk ow s k i, 1992).
Sweet pepper is used as a vegetable as well as a spice, medicinal, and ornamental plant. The fruit of sweet pepper is a not very juicy berry with a leathery outer coat up to $15 \mathrm{~cm}$ long and $4 \mathrm{~cm}$ wide ( $\mathrm{S} \mathrm{z}$ w e y k o w s c y, 2003). Some species and cultivars produce small inner berries inside the main fruit (Carballo-Bautista et al. 2010). The authors of the above-mentioned paper defined the morphological and anatomical characters of these additional fruits in Capsicum chinense.

Capsaicin, an alkaloid that is produced in the placenta from whence it penetrates into seeds and the pericarp, gives a pungent, unique taste to the pepper fruit (P o d b i e l k ow s k i, 1992). Sweet pepper berries also contain essential oils, antibiotic capsaicin, provitamin $A$, vitamins $B_{2}, B_{1}, P P$, and a very large amount of vitamin C (P o d b i e l k ow s k i, 1992).

Li m et al. (2007) report on the sensitivity of red pepper fruits to low temperatures during storage depending on the maturity stage, showing anatomical changes in the fruit relating to the destruction of parenchyma and collenchyma cells.

The aim of this paper is to show the micromorphology and internal structure of the pericarp and fruit pedicle of sweet pepper, since sparse data have been found on this issue in the literature.

\section{MATERIALS AND METHODS}

The present study investigated the structure of the fruit and pedicle of Capsicum annuит L., cv. 'Red Knight $F_{1}$ '. This is a cultivar that is now recommended for cultivation both in shade houses and in open field. Fruits of this cultivar are large $(11 \times 11 \mathrm{~cm}), 3-4$-chambered, and thick-walled (8-9 mm). They change colour from dark green to deep red easily and quickly. The skin of the fruit 
is shining and smooth and does not crack even in cold autumn weather. Fruits are borne on long pedicles; after harvest they preserve very good quality for a long time.

The plants were grown in a greenhouse in $10 \mathrm{dcm}^{3}$ cylinders filled with peat growing medium. Throughout the whole growing period, nutrients in the medium were maintained at a level optimal for this vegetable. Healthy, fully red fruits were sampled for microscopic analysis in the middle of the fruiting period.

Light microscopy (LM) and scanning electron microscopy (SEM) were used for the investigations. For LM observations, fresh specimens were prepared and specimens fixed in $70 \%$ ethanol. Hand-cut sections were mounted in 50\% glycerol. Histochemical tests were performed to detect the presence of cutin in the cell walls (Sudan III).

For SEM investigations, fruit and pedicle samples were fixed in $4 \%$ glutaraldehyde and $0.1 \mathrm{M}$ phosphate buffer at a $\mathrm{pH}$ of 7.0. Next, the sections were rinsed and dehydrated in ethanol and acetone series. After critical-point drying in $\mathrm{CO}_{2}$, the specimens were sputter-coated with gold using an Emitech K550 x sputter coater. Observations were carried out under a TESCAN VEGA II LMU microscope.

\section{RESULTS}

\section{Micromorphology of the pericarp epidermis}

Viewed in SEM, the outer epidermis of the pericarp (exocarp) is composed of different sized cells with a quadrangular outline (Fig. 1 A, B, E, F). Their outer walls were covered by a substantial layer of cuticle that causes the cell contours to be poorly visible. The cuticle surface exhibits distinct granular protrusions, small striae, and cracks.

A wax layer can be observed at some places of the epidermis (Fig. 1 D, G). The skin of the pericarp is sometimes slightly folded (Fig. 1 F). Stomata are found in the epidermis very rarely. They are covered by a massive layer of cuticle (Fig. $1 \mathrm{C}$ ).

\section{Anatomy of the pericarp}

The following tissues were successively viewed on microscope slides prepared from a fresh pericarp of red pepper: outer epidermis, collenchyma, parenchyma, vascular bundles, and inner epidermis surrounding the seed chambers. A characteristic feature of the protoplasts of the first three tissues was the occurrence of numerous, different coloured (orange and red) chromoplasts in them (Fig. 2 A-G).

The outer epidermis (exocarp) was composed of a single layer of cells which height was $26-30 \mu \mathrm{m}$ with a very thick outer wall (13-15 $\mu \mathrm{m})$ that exhibited a yellowish colour (Fig. 2 A-E). Straight pits were found in the cell walls adjacent to the collenchyma (Fig. 2 B) and in the anticlinal walls (Fig. 2 D, E).
The next tissues, collenchyma and parenchyma, as well as the vascular bundles formed the mesocarp layer. The collenchyma, located subepidermally, consisted of 5-7 layers and represented the tangential collenchyma type in its outer tiers, whereas the next layers were composed of angular collenchyma (Fig. 2 F). The parenchymal cells had thin cellulose walls and increasing dimensions toward the centre of the pericarp. They contained large cell nuclei (Fig. 2 A), which were sometimes lobed (Fig. $2 \mathrm{H}$ ). The bicollateral vascular bundles contained annular and spiral vessels.

The inner epidermis (endocarp) consisted of one layer of cells. Their walls were strongly thickened and folded and they were characterized by the presence of numerous straight pits (Fig. 2 I).

\section{Micromorphology of the epidermal surface of the pedicle}

The stem (pedicle) holding the fruit has an irregular shape and varying thickness. In its middle part, the pedicle is slightly flattened, while in the upper portion it is circular in cross-sectional view with a strong expansion at the base of the fruit. The pedicle shows ribs and depressions of varying depth along its entire length.

The epidermal cells have a quadrangular shape. The stomata are distributed irregularly (Fig. 3 A-C). The surface of the epidermis of the examined stem is covered by a cuticle and wax. The cuticle locally forms folds on the surface of the cells, most frequently in the vicinity of the stomata (Fig. 3 C-E). In some regions of the stem, vesicular protrusions are visible on the surface of the epidermal cells, probably containing essential oil that accumulates there and which can be found in various organs of red pepper (Fig. $3 \mathrm{C}$ ).

The stomata are arranged in different directions in the small depressions of the epidermis. They have very well-developed outer cuticular ledges (Fig. 4 D-F). At the fully ripe stage of the fruit, smaller stomata, not functioning and with the closed pore covered by a cuticle, could be observed among the fully developed stomata. The average stomata length was $34 \mu \mathrm{m}$.

\section{Anatomy of the pedicle}

The epidermis of the pedicle of red pepper is composed of a thin layer (Fig. 4 A, B) whose cells reach a height of $25 \mu \mathrm{m}$, and the thickness of the outer wall was $5,5 \mu \mathrm{m}$. The first layer of subepidermal parenchyma, adjacent to the epidermis, is marked by small cell dimensions (Fig. 4 A, B). The collenchyma strengthening the stem does not produce a continuous layer, but forms local clusters consisting of 2-3 layers of cells (Fig. 4 A). The multi-layered chlorenchyma of the stem shows the presence of very large intercellular spaces, which are evidence of intense gas exchange and the high activity of the cells of this region (Fig. 4 A-C). Numerous chloroplasts occur in the protoplasts of the epidermis, collenchyma, and parenchyma cells. 
In their circumferential part, the vascular tissue layers are surrounded by small clusters of sclerenchyma fibres (3-5), which perform supporting functions.

In the phloem layer, there are cells, dispersed in groups of 1-2, containing calcium oxalate crystals. The layers of secondary phloem and xylem, forming rings around the pith, reach a different thickness in the pedicle cross section. The central part of the stem comprises the pith composed of large-diameter parenchymal cells with very numerous pits on all the walls, (Fig. 4 D). resembling short tracheids (Fig. 4 D).
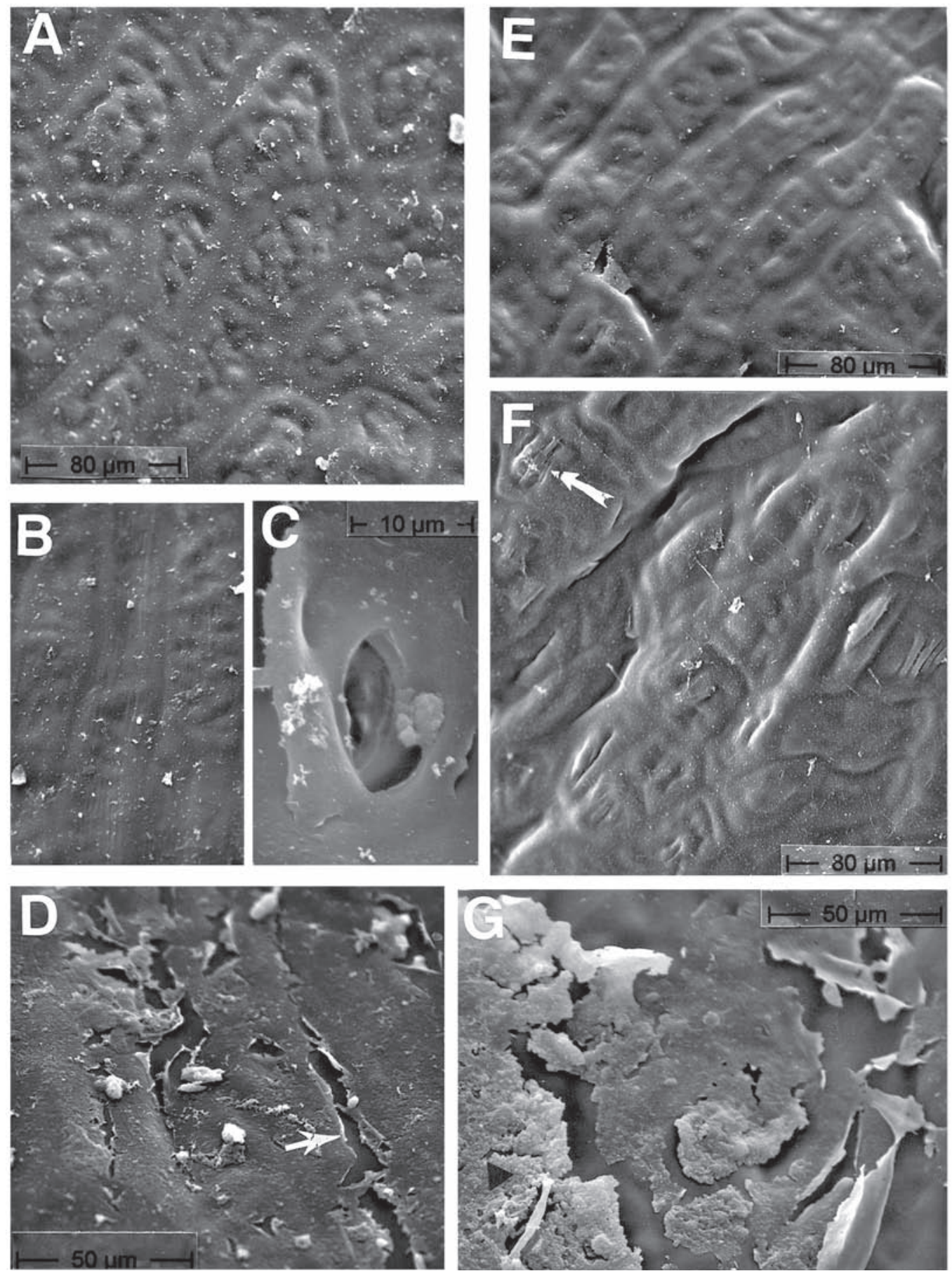

Fig. 1. Epidermal surface of the pericarp of Capsicum annuит L. (SEM).

A, B, E, F - Poorly visible contours of the epidermal cells covered by a thick layer of cuticle; F - the surface of the epidermis exhibits folds and local striae (arrows);

$\mathrm{C}$ - One of the few stomata in the pericarp, surrounded by a thick layer of cuticle;

$\mathrm{D}, \mathrm{G}-$ Visible local cracks of the cuticle (arrow) and a wax layer (arrowhead). 

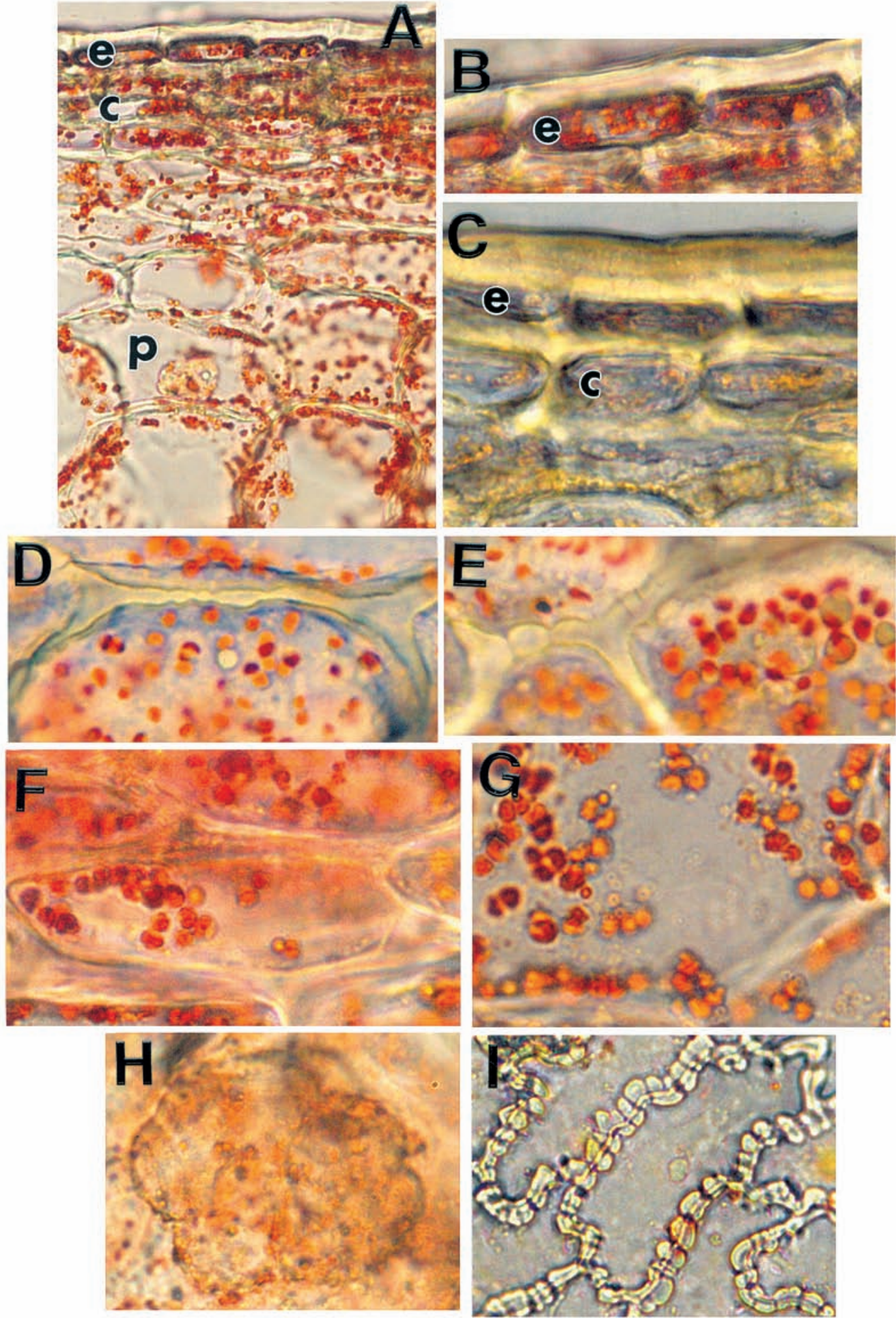

Fig. 2. Cross sections of the pericarp of red pepper and portions of epidermal cells in dorsal view (LM, fresh specimens).

A - Cross-sectional portion with the visible epidermis (e), collenchyma (c), and parenchyma (p) with numerous chromoplasts in the cells; $\times 300$;

B, C - Cells of the epidermis and of the subepidermal layers: visible are thick outer walls of the epidermis (e) and lamellar thickenings of the collenchyma cell walls (c); B $-\times 400$; C $-\times 600$;

D, E - Top view of the epidermal cells with straight pits in the radial walls and numerous chromoplasts; $\times 1200$;

F - Prosenchymatous cells of the collenchyma; $\times 800$;

$\mathrm{G}-$ Part of a thin-walled parenchymal cell with different coloured chromoplasts; $\times 800$;

$\mathrm{H}-$ Strongly enlarged, lobed nucleus in a parenchymal cell; $\times 1200$;

I - Endocarp cells with thick walls and straight pits; $\times 600$. 

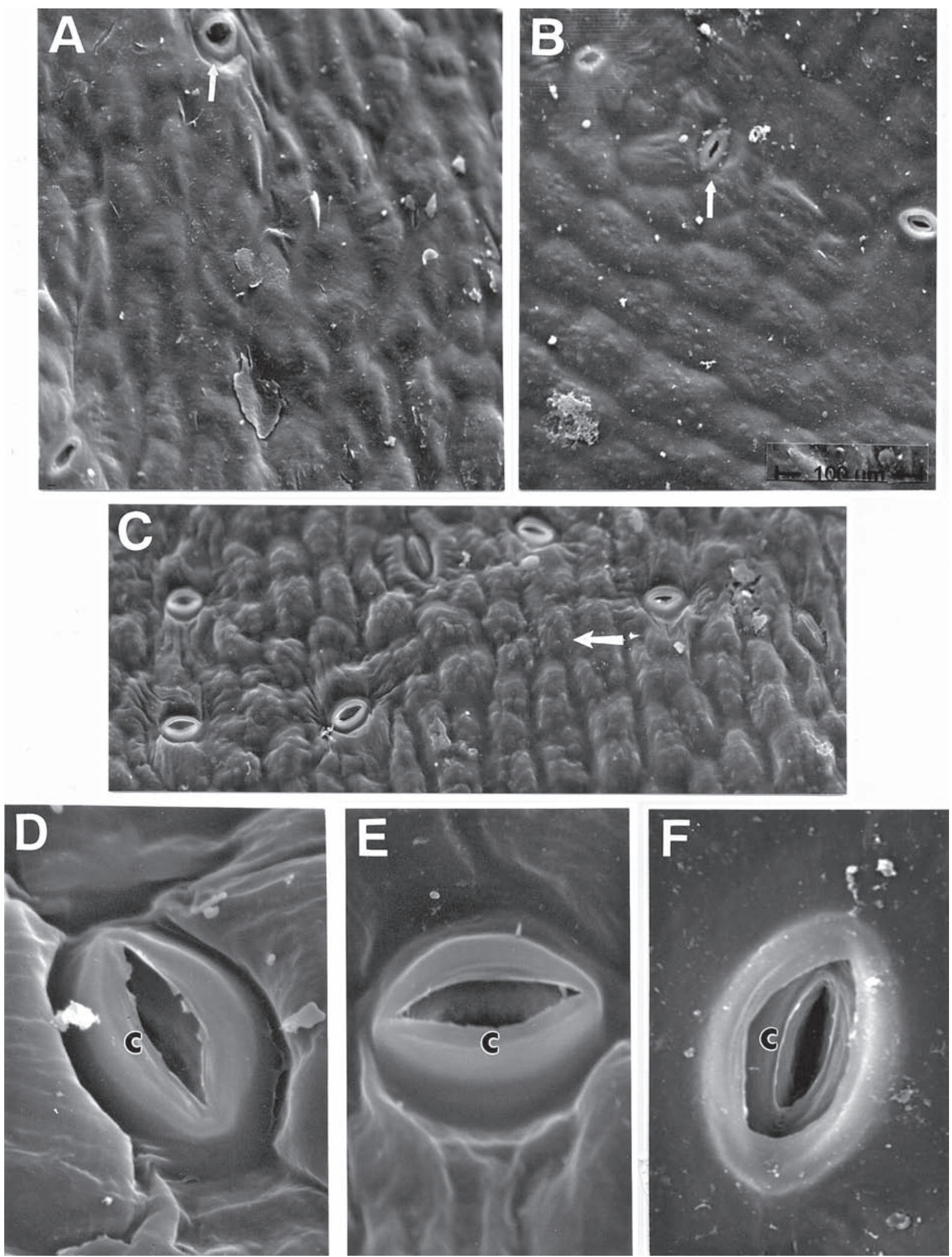

Fig. 3. Surface portions of the epidermis of the pedicle in Capsicum annuum L. (SEM).

A, B, C-Epidermal cells from different places of the pericarp with stomata (arrows) - a regular cell arrangement can be seen; $\mathrm{C}$ - Droplets of secretion are visible beneath the cuticle layer (arrows);

D, E, F - Stomata from the epidermis of the pedicle with well-developed outer cuticular ledges. 

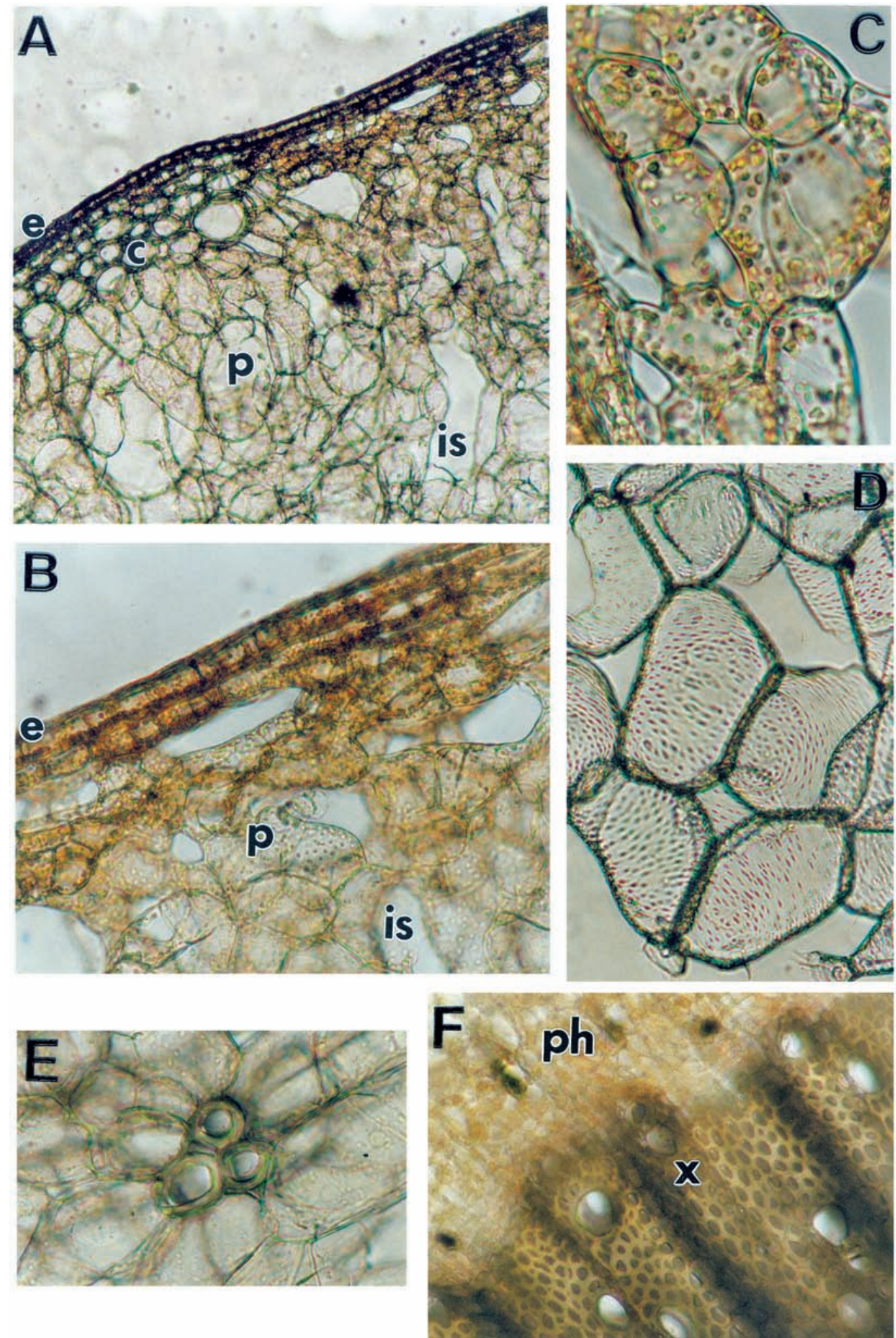

Fig. 4. Cross-sectional portions of the pedicle of Capsicum annuиm L..

A, B - Outer part with the epidermis (e), collenchyma (c), and parenchyma (p) with very numerous intercellular spaces (is); $\mathrm{A}-\times 80$; $\mathrm{B}-\times 200$;

C - Parenchymal cells with chloroplasts; $\times 400$;

$\mathrm{D}-$ Cells of the pith with numerous pits in the walls; $\times 100$;

E - Sclerenchyma fibres surrounded by parenchymal cells; $\times 320$;

$\mathrm{F}$ - Vascular tissues of the pedicle: xylem (x), phloem (ph); $\times 120$. 


\section{DISCUSSION}

Adaptations to hot climate zones can be observed in the structure of the organs of the studied red pepper cultivar. The fruit structure is characterized by an exceptionally thick outer wall of the epidermal cells, which is covered by a massive cuticle and a wax layer. Relatively thick outer walls are also found in the epidermal cells of the pedicle. Fis cher and Fari (1983) drew attention to strong cutinization of the cell walls of the outer layers of the pericarp in red pepper. In histochemical investigations, they distinguished several red pepper cultivars marked by increased resistance due to a significant content of cutin. At the same time, these authors stressed that these cultivars were characterized by poorer digestibility.

The occurrence of straight pits in the epidermal cell walls in the fruit of the cultivar under investigation as well as between the epidermal cells and the collenchyma is evidence of active exchange of substances between them during fruit ripening.

The presence of chromoplasts in the epidermal cells of red pepper and of many subepidermal layers enhances the intense colouration of the fruit. At the same time, their appearance is a symptom of plant organ senescence. Chromoplasts are found in the tissues of low physiological activity ( $\mathrm{S}$ z w e y k ow s c y, 2003).

O l s ze w s k a (1971) reports that accumulated carotenoids occur in the stroma of the chromoplasts in red cultivars of Capsicum annuиm. They are located both in the plastoglobules and in the fibrous structures of these plastids. Evert (2006) states, that chromoplasts are classified entirely on the structure of the carotenoid - bearing components present in the mature plastid. In red fruits of Capsicum occur tubular chromoplasts, in which the carotenoids are incorporated into filamentous lipoprotein "tubules".

The different colours of chromoplasts which were observed, red or orange, can result from uneven maturation of these plastids and different contents of carotenoids.

The subepidermal layers of the pericarp, comprising the collenchyma and parenchyma, show high sensitivity to low temperature storage at earlier fruit maturity stages. These tissues undergo strong deformations, as shown by the study of Li m et al. (2007). This is probably attributable to the poor rigidity of the cellulose walls in the above-mentioned tissues at particular maturation stages.

In the pedicle of the studied Capsicum annuum cultivar, we observed small clusters of sclerenchyma fibres in the peripheral parts of the phloem. Studies of other authors show that there is a different content of sclereids in the upper portion of the pedicle and at the basal part of the fruit in particular C. аппиит and
C. frutescens cultivars, which is important during fruit harvest since this is an undesirable feature if the fruit separates from the receptacle too easily $(\mathrm{Ge} \mathrm{r} \mathrm{s} \mathrm{ch} \mathrm{et}$ al. 1998; S u nd berg et al. 2003; A l- K h a ti b and $\mathrm{S} \mathrm{und}$ b e rg , 2006). These authors found that the degree of sclerification of the fruit pedicle in red pepper plays a large role in its brittleness during fruit harvest. They also demonstrated that the sclerenchyma matured faster in the outer region of the pedicle than in the central one.

In our study, we observed that the stomata were distributed unevenly in the epidermis of the pedicle and that they occurred very rarely in the fruit epidermis. In the pedicle, they reach a significant length $(34 \mu \mathrm{m})$ and are characterized by well-developed outer cuticular ledges, which is typical of dry area plants. De T o m a et al. (1983) showed that stomatal length in the leaves of $C$. annuum was genetically determined.

\section{REFERENCES}

A 1-Khatib, Sundberg M.D., 2006. Sclereid development during fruit ripening in two lines of Tabasco pepper (Capsicum frutescen). Transaction Kansas Acad. Sci. 109 (1/2): 58-66.

Carballo-Bautista M. A., Moguel-Salazar F., Brito-Argaez L., Cristobal-Alejo J., Islas-Flores J., 2010. A brief morphological description of small internal fruit grown in habanero pepper (Capsicum chinense Jacq.) main fruit. Rev. Fitotec. Mex. 33(4):281-285.

De Toma C., Silvetti E., Bioni M., 1983. Genetics of stomatal length in pepper (Capsicum annuum L.). Capsicum Newsletter, 2:37-39.

Evert R.F., 2006. Esau's Plant Anatomy. John Wiley and Sons, Inc.

Fischer I., Fari M., 1983. Exocarp anatomy and consumption type in Capsicum. Capsicum Newsletter, 2:27-29.

Gersch K.P., Motsenbocker C.E., Lang G.A., 1998. Anatomical description of the Fruit - Receptacle Detachment Area in Cayenne Pepper. J. Amer. Soc. Hort. Sci. 123(4):550-555.

Lim Ch.S., Kang S.M., Cho J.L., 2007. Bell Pepper (Capsicum annuum L.) Fruits are Susceptible to Chilling Injury at the Breaker Stage of Ripeness. Hort. Science. 42(7):1659-1664.

Nowiński M., 1977. Dzieje roślin i upraw ogrodniczych. Państwowe Wydawnictwo Rolnicze i Leśne, Warszawa. (in Polish)

Olszewska M., 1971. Cytologia roślin. Państwowe Wydawnictwo Naukowe. Warszawa. (in Polish)

Podbielkowski Z., 1992. Rośliny użytkowe. Wydawnictwo Szkolne i Pedagogiczne. (in Polish)

Sundberg M.D., Motsenbocker C.E., Huang Y., 2003. Anatomy of fruit detachment in tabasco pepper 
(Capsicum frutescens, Solanaceae). J. Torr. Bot. Soc. 130(4):231-237.

Szweykow s cy A., J., 2003. Słownik botaniczny. Wiedza Powszechna, Warszawa (in Polish)

\section{Cechy anatomiczne owoców papryki słodkiej (Capsicum annuum L.)}

\section{Streszczenie}

Przy zastosowaniu mikroskopii świetlnej oraz skaningowej elektronowej badano mikromorfologię epidermy oraz anatomię owocni i szypułki owoców Capsicum annuиm L. cv. 'Red Knight $\mathrm{F}_{1}$ '. Stwierdzono, że owocnię tworzy epiderma o silnie zgrubiałych ścianach zewnętrznych, kilka warstw kolenchymy płatowej i kątowej oraz wielowarstwowa parenchyma o zróżnicowanych pod względem wielkości komórkach, w których obserwowano bardzo duże płatowate jądra. W komórkach wymienionych tkanek występowały chromoplasty. Wewnętrzna epiderma owocni wyróżniała się grubymi ścianami komórek oraz licznymi jamkami prostymi.

Wśród tkanek szypułki obserwowano epidermę z licznymi aparatami szparkowymi, kolenchymę, chlorenchymę z bardzo dużymi przestworami międzykomórkowymi, niewielkie skupienia sklerenchymy, wtórny floem i ksylem oraz martwe komórki rdzenia, które charakteryzowały się obecnością cienkich ścian z licznymi jamkami. Cechy budowy owocni badanej odmiany papryki wskazują na przystosowania do znacznego ograniczenia transpiracji, co stanowi ważną cechę w czasie przechowywania. Równocześnie silnie zgrubiałe i skutynizowane ściany owoców przyczyniają się do zmniejszenia ich strawności. 